\title{
A novel lectin with antiproliferative activity from the medicinal mushroom Pholiota adiposa
}

\author{
G. Q. Zhang ${ }^{1}$, J. Sun ${ }^{1}, \mathrm{H}$. X. Wang ${ }^{1 凶}$ and T. B. $\mathrm{Ng}^{2 \bowtie}$ \\ ${ }^{1}$ State Key Laboratory for Agrobiotechnology and Department of Microbiology, China Agricultural University, \\ Beijing, China; ${ }^{2}$ School of Biomedical Sciences, Faculty of Medicine, The Chinese University of Hong Kong, \\ Shatin, New Territories, Hong Kong, China
}

Received: 24 March, 2009; revised: 08 May, 2009; accepted: 22 July, 2009 avialable on-line: 27 July, 2009

\begin{abstract}
Little was known about biological activities of compounds from the medicinal mushroom of the genus Pholiota. A lectin from the Pholiota adiposa has now been isolated and its properties tested. The isolation procedure included ion exchange chromatography on DEAE-cellulose and CM-cellulose, and fast protein liquid chromatography-gel filtration (FPLC) on Superdex 75 . The lectin was composed of two identical subunits, each with a molecular mass of $16 \mathrm{kDa}$. Its N-terminal amino-acid sequence showed little similarity to sequences of other Agaricales lectins. The hemagglutinating activity of the lectin was stable at temperatures up to $50^{\circ} \mathrm{C}$, and in $\mathrm{NaOH}$ and $\mathrm{HCl}$ solutions with concentrations less than $25 \mathrm{mM}$. It was inhibited by inulin (12.5-200 mM), but enhanced by $\mathrm{Cu}^{2+}(6.25-25 \mathrm{mM}), \mathrm{Fe}^{2+}(12.5-25 \mathrm{mM})$, and $\mathrm{Al}^{3+}(6.25-25 \mathrm{mM})$ ions. The lectin showed antiproliferative activity toward hepatoma Hep G2 cells and breast cancer MCF7 cells with an $\mathrm{IC}_{50}$ of $2.1 \mu \mathrm{M}$ and approximately $3.2 \mu \mathrm{M}$, respectively. It exhibited HIV-1 reverse transcriptase inhibitory activity with an $\mathrm{IC}_{50}$ of $1.9 \mu \mathrm{M}$. When compared with $P$. aurivella lectin, the only Pholiota lectin published to date, P. adiposa lectin differs in chromatographic behavior, molecular mass, $\mathrm{N}$-terminal sequence, and effect of cations on hemagglutinating activity. In the case of the lectin from $P$. aurivella, its antifungal, antiproliferative, and HIV-1 reverse transcriptase inhibitory activities have not been determined.
\end{abstract}

Keywords: lectin, Pholiota adiposa, purification, mushroom, antiproliferative

\section{INTRODUCTION}

Lectins are proteins or glycoproteins of nonimmune origin which have a wide distribution in animals, plants, and microorganisms. They can agglutinate cells through sugar-specific binding sites for polysaccharides and glycoconjugates (Guillot \& Konska, 1997; Wang et al., 1998; Ho et al., 2004). In mushrooms, lectins are present in the caps, stipes, spores, and mycelia. The content of lectin varies depending on the age of the carpophore and the time and place of harvest. Mushroom lectins play an important role in dormancy, growth, morphogenesis, morphological changes consequent on parasitic infections and molecular recognition during the early stages of mycorrhization (Guillot \& Konska, 1997; Ng, 2004). It has been reported that mushroom lectins manifest various exploitable actoins including antiproliferative (Liu et al., 2006), antitumor (Wang et al., 2000; Han et al., 2005), immunomodulatory (Wang et al., 1996), and mitogenic (Wang et al., 2002; Ngai \& Ng, 2004) activities. Lectins have been isolated from several common edible mushrooms, including Agaricus bisporus, Flammulina velutipes, Ganoderma lucidum, Grifola frondosa, Hericium erinaceum, Pleurotus ostreatus, and Volvariella volvacea (Pemberton, 1984; $\mathrm{Ng}, 2004)$.

${ }^{\square}$ Corresponding authors: H.X. Wang, State Key Laboratory for Agrobiotechnology and Department of Microbiology, China Agricultural University, Beijing 100094, China; e-mail: hxwang@cau.edu.cn; T.B. Ng, School of Biomedical Sciences, Faculty of Medicine, The Chinese University of Hong Kong, Shatin, New Territories, Hong Kong, China; e-mail: b021770@ mailserv.cuhk.edu.hk.

Abbreviations: DEAE, diethylaminoethyl; CM, carboxymethyl; HPLC, high performance liquid chromatography; ELISA, enzyme-linked immunosorbent assay; RT, reverse transcriptase; PAL, Pholiota adiposa lectin; SDS, sodium dodecyl sulfate. 
Pholiota adiposa is an edible as well as a medicinal mushroom cultured in China and Japan. It belongs to Agaricales (Strophariaceae), and has antitumor, antimicrobial, antihypertensive, and antihyperlipidemic activities. An extract of $P$. adiposa inhibited the growth of sarcoma 180 and Ehrlich solid cancers in mice (Yu et al., 2007). Further research suggested that the antitumor activity of $P$. adiposa polysaccharide was due to immunostimulation (Zhao et al., 2007). A novel pentapeptide (Gly-Glu-Gly-GlyPro) with angiotensin converting enzyme inhibitory activity was isolated from the fruiting body of $P$. adiposa (Izawa \& Aoyagi, 2006; Koo et al., 2006). Stigmasterol purified from methanol extracts of $P$. adipo$s a$ fruiting bodies inhibited $\beta$-hydroxy- $\beta$-methyl-glutaryl coenzyme A reductase, a rate-limiting enzyme in cholesterol biosynthesis, with an $\mathrm{IC}_{50}$ of $6.8 \mathrm{\mu g} / \mathrm{ml}$ (Yu et al., 2007). A P. adiposa extract did not produce any significant change in total triglyceride contents or epididymal fat mass, but caused a decrease in retroperitoneal fat in mice on a high-fat diet (Cho et al., 2006). The present investigation aimed to isolate and characterize a lectin from the fruiting bodies of $P$. adiposa and to find out if it has some distinctive characteristics. To date only one lectin has been isolated from a representative of the Pholiota genus, Pholiota aurivella (Kawagishi et al., 1991).

\section{MATERIALS AND METHODS}

Isolation of lectin. Dried fruiting bodies of the mushroom $P$. adiposa (100 g) cultured in the Department of Microbiology of China Agricultural University, were homogenized in $0.15 \mathrm{M} \mathrm{NaCl}(10 \mathrm{ml} / \mathrm{g})$ at $4^{\circ} \mathrm{C}$ and extracted overnight at $4^{\circ} \mathrm{C}$. Then the homogenate was centrifuged at $8000 \times g$ for $15 \mathrm{~min}$. To the supernatant $\left(\mathrm{NH}_{4}\right)_{2} \mathrm{SO}_{4}$ was added to $80 \%$ saturation. The mixture was left at $4^{\circ} \mathrm{C}$ for $4 \mathrm{~h}$ before centrifugation at $8000 \times g$ for $15 \mathrm{~min}$. The precipitate was redissolved and dialyzed to remove $\left(\mathrm{NH}_{4}\right)_{2} \mathrm{SO}_{4}$ before applying to a DEAE-cellulose (Sigma) column $(2.5 \times 20 \mathrm{~cm})$ in $10 \mathrm{mM} \mathrm{NH}_{4} \mathrm{HCO}_{3}$ buffer $(\mathrm{pH} 9.4)$. After removal of the unadsorbed peak (D1), three adsorbed peaks, D2, D3 and D4, were eluted stepwise with $50 \mathrm{mM} \mathrm{NaCl}, 150 \mathrm{mM} \mathrm{NaCl}$ and $1 \mathrm{M} \mathrm{NaCl}$ in the buffer, respectively. Fraction D3 was then passed through a CM-cellulose (Sigma) column $(1.5 \times 10 \mathrm{~cm})$ which had been equilibrated and then eluted with $10 \mathrm{mM} \mathrm{NH} \mathrm{NHAc}_{4} \mathrm{OH}$ 4.6). Unbound material ((fractions C1) was eluted with the starting buffer, while bound proteins (fractions C2, C3) were desorbed sequentially with $50 \mathrm{mM} \mathrm{NaCl}$ and $1 \mathrm{M} \mathrm{NaCl}$ in the starting buffer. The active peak (C2) was subsequently purified by fast protein liquid chromatography (FPLC) on a gel filtration Superdex 75 HR 10/30 column (GE Healthcare) in $0.15 \mathrm{M} \mathrm{NH}_{4} \mathrm{HCO}_{3}$ buffer
( $\mathrm{pH}$ 8.5). The second peak (SU2) obtained constituted a purified lectin.

Determination of molecular mass and N-terminal sequence. The purified lectin was subjected to sodium dodecyl sulfate/polyacrylamide gel electrophoresis (SDS/PAGE) for molecular mass determination in accordance with the procedure of Laemmli and Favre (1973). Gel filtration on an FPLC-Superdex 75 column, which had been calibrated with molecular mass markers (GE Healthcare), was conducted to determine the native molecular mass of the lectin. The N-terminal sequence of the lectin was determined by using a Hewlett-Packard HP G1000A Edman degradation unit and an HP 1000 HPLC System (Wang et al., 2002).

Assay for lectin (hemagglutinating) activity. In the assay, a serial twofold dilution of the lectin solution in microtiter U-plates $(25 \mu \mathrm{l})$ was mixed with $25 \mu \mathrm{l}$ of a $2 \%$ suspension of rabbit red blood cells in phosphate-buffered saline $(\mathrm{pH} 7.2)$ at $20^{\circ} \mathrm{C}$. The results were recorded after about $1 \mathrm{~h}$ when erythrocytes in the blank had fully sedimented. The hemagglutination titer, defined as the reciprocal of the highest dilution exhibiting hemagglutination, was reckoned as one hemagglutination unit. Specific activity is the number of hemagglutination units/mg protein (Wang et al., 2000).

Hemagglutinating inhibition tests to investigate the inhibition of lectin-induced hemagglutination by various carbohydrates were performed in a manner analogous to the hemagglutination assay. The carbohydrates tested included inositol, Lsorbose, raffinose, L-rhamnose, D-fructose, D-mannose, cellobiose, L-arabinose, D-xylose, D-melibiose, lactose, inulin, maltose, D-galactose, D-glucose and O-nitrophenyl- $\beta$-D-galactopyranoside. Serial twofold dilutions of sugar samples were prepared in phosphate-buffered saline $(\mathrm{pH} \mathrm{7.2)}$. All of the dilutions were mixed with an equal volume $(25 \mu \mathrm{l})$ of a solution of the lectin with 16 hemagglutination units. The mixture was allowed to stand for $30 \mathrm{~min}$ at room temperature and then mixed with $50 \mu \mathrm{l}$ of a $2 \%$ rabbit erythrocyte suspension. The minimum concentration of the sugar in the final reaction mixture which completely inhibited 16 hemagglutination units of the lectin preparation was calculated (Han et al., 2005).

The effects of temperature, $\mathrm{NaOH}, \mathrm{HCl}$, and metallic chlorides on the hemagglutinating activity of the lectin were determined as previously described (Wang et al., 1996).

Assay of antiproliferative activity on tumor cell lines. The tumor cell lines, human breast cancer (MCF 7) and hepatoma (Hep G2), were purchased from American Type Culture Collection (ATCC). They were maintained in Dulbecco modified Eagle's medium (DMEM) supplemented with 
Table 1. Summary of purification of $P$. adiposa lectin.

Activity refers to hemagglutinating activity.

\begin{tabular}{|c|c|c|c|c|c|}
\hline Fraction & $\begin{array}{l}\text { Yield } \\
(\mathrm{mg} / 100 \mathrm{~g})\end{array}$ & $\begin{array}{l}\text { Specific activity } \\
\text { (units/mg) }\end{array}$ & $\begin{array}{l}\text { Total activity } \\
\text { (units) }\end{array}$ & $\begin{array}{l}\text { Recovery of activity } \\
(\%)\end{array}$ & $\begin{array}{l}\text { Fold of } \\
\text { purification }\end{array}$ \\
\hline Crude extract & 6301 & 283 & $1.8 \times 10^{6}$ & 100 & 1 \\
\hline D3 & 556 & 2412 & $1.3 \times 10^{6}$ & 72.2 & 8.5 \\
\hline $\mathrm{C} 2$ & 143 & 7690 & $1.1 \times 10^{6}$ & 61.1 & 27.2 \\
\hline SU2 & 70 & 10988 & $7.7 \times 10^{5}$ & 42.8 & 38.8 \\
\hline
\end{tabular}

$10 \%$ fetal bovine serum (FBS), $100 \mathrm{mg} / \mathrm{l}$ streptomycin and $100 \mathrm{IU} / \mathrm{ml}$ penicillin at $37^{\circ} \mathrm{C}$ in a humidified atmosphere of $5 \% \mathrm{CO}_{2}$. Cells $\left(1 \times 10^{4}\right)$ in their exponential growth phase were seeded into each well of a 96-well culture plate (Nunc, Denmark) and incubated for $3 \mathrm{~h}$ before addition of the lectin. Incubation was carried out for another $48 \mathrm{~h}$. Radioactive precursor, $1 \mu \mathrm{Ci}$, ([ ${ }^{3} \mathrm{H}$-methyl] thymidine, from GE Healthcare) was then added to each well and incubated for $6 \mathrm{~h}$. The cultures were then harvested by a cell harvester. The incorporated radioactivity was determined by liquid scintillation counting (Li et al., 2009).

Assay for HIV-1 reverse transcriptase inhibitory activity. The inhibitory activity towards human immunodeficiency virus type 1 (HIV)-1 reverse transcriptase (RT) was assessed by using an enzyme-linked immunosorbent assay (ELISA) kit from Boehringer Mannheim (Germany). The assay takes advantage of the ability of reverse transcriptase to synthesize DNA, starting from the template/primer hybrid poly(A)-oligo(dT) ${ }_{15}$. The digoxigenin- and biotin-labeled nucleotides in an optimized ratio are incorporated into the DNA molecule synthesized by the RT. The detection and quantification of the synthesized DNA as a measure of RT activity follows

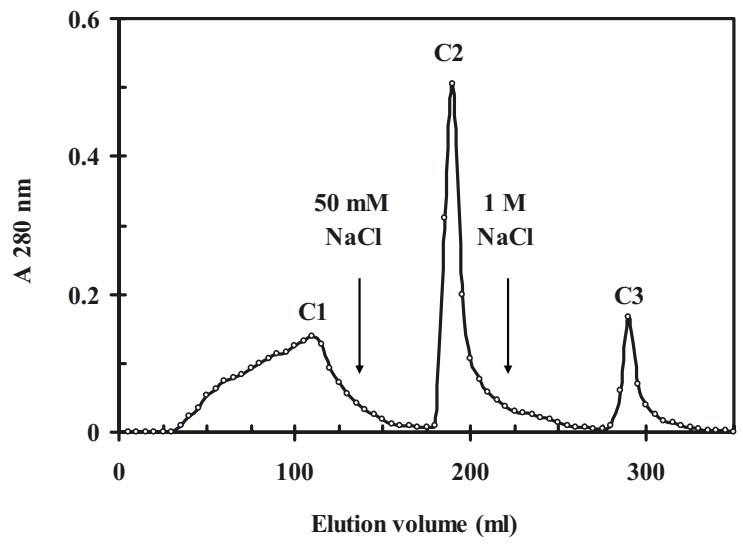

Figure 1. Ion exchange chromatography of fraction D3 (adsorbed on DEAE-cellulose) on CM-cellulose.

A CM-cellulose column $(1.5 \times 10 \mathrm{~cm})$ was equilibrated and eluted with $10 \mathrm{mM} \mathrm{NH} \mathrm{mHAC}_{4} \mathrm{Ouffer}$ ( $\mathrm{pH}$ 4.6) and then stepwise with $50 \mathrm{mM}$ and $1 \mathrm{M} \mathrm{NaCl}$ in the same buffer. Arrows indicate the points at which buffer was changed. sandwich ELISA protocol. A fixed amount (4-6 ng) of recombinant HIV-1 RT was used. The inhibitory activity of the lectin was calculated as percent inhibition as compared to a control without the protein (Wang \& Ng, 2004).

Assays for antifungal and ribonuclease activities. The assays were conducted as described in (Han et al., 2005; Wang \& Ng, 2006), respectively.

\section{RESULTS}

\section{Isolation of lectin}

One of the fractions adsorbed on DEAEcellulose, fraction D3, showed hemagglutinating activity (Table 1). Ion exchange chromatography on CM-cellulose resulted in an unadsorbed fraction $\mathrm{C} 1$ and two adsorbed fractions $\mathrm{C} 2$ and $\mathrm{C} 3$ (Fig. 1). The lectin activity resided in fraction $\mathrm{C} 2$ (Table 1). Subsequently, fraction C2 was resolved into a smaller peak SU1 and a larger peak SU2 upon gel filtration on a Superdex 75 HR 10/30 column by FPLC on an AKTA Purifier (GE Healthcare; Fig. 2). The hemagglutinating activity was

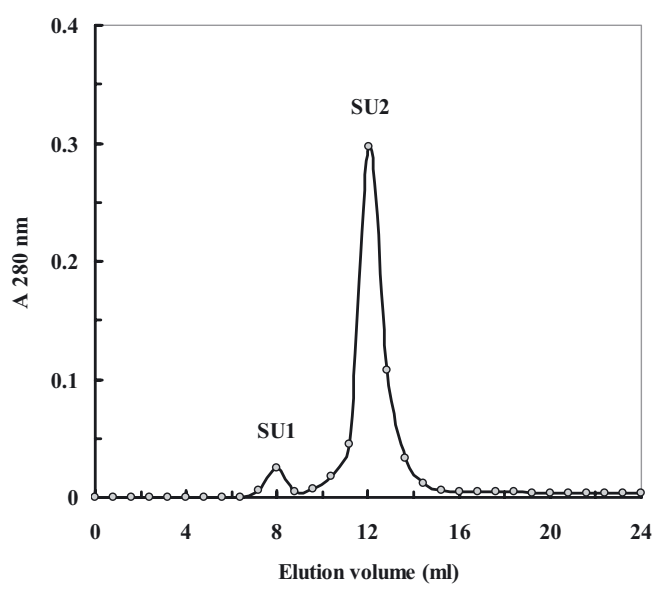

Figure 2. Gel filtration of fraction C2 from CM-cellulose column on Superdex 75.

A Superdex 75 (HR 10/30) column was eluted with $0.15 \mathrm{M}$ $\mathrm{NH}_{4} \mathrm{HCO}_{3}$ buffer ( $\mathrm{pH}$ 8.5). The flow rate was $0.4 \mathrm{ml} / \mathrm{min}$. Fraction SU2 represents purified lectin. 
Table 2. Comparison of $\mathrm{N}$-terminal sequence of $P$. adiposa lectin with sequences of known Agaricales lectins.

\begin{tabular}{lll}
\hline Species & N-terminal sequence & Reference \\
\hline Pholiota adiposa & DILMGTYGML & This study \\
Pholiota aurivella & YSVTTPNSVKGGTNQPGA & Kawagishi et al. $(1991)$ \\
Agaricus bisporus & MGGSGTSGSL & Crenshaw et al. $(1995)$ \\
Agrocybe aegerita & NISAGTSVDL & Zhao et al. $(2003)$ \\
Coprinopsis cinerea & IPLEGTFGDR & Walti et al. $(2008)$ \\
Flammulina velutipes & TSLTFQLAYL & Ko et al. $(1995)$ \\
Laccaria bicolor & SHLYGDGVAL & Martin et al. $(2008)$ \\
Marasmius oreades & YILDGEYLVL & Kruger et al. $(2002)$ \\
Pleurotus cornucopiae & SDSTWTFAML & Oguri et al. $(1996)$ \\
\hline
\end{tabular}

Table 3. Effect of temperature on hemagglutinating activity of $P$. adiposa lectin.

Initial hemagglutinating activity was $16 \mathrm{U}$.

\begin{tabular}{llllllllll}
\hline Temperature $\left({ }^{\circ} \mathrm{C}\right)$ & 20 & 30 & 40 & 50 & 60 & 70 & 80 & 90 & 100 \\
\hline Hemagglutinating activity remained $[\%]$ & 100 & 100 & 100 & 100 & 25 & 0 & 0 & 0 & 0 \\
\hline
\end{tabular}

enriched in SU2. About 40-fold purification was achieved (Table 1).

\section{Molecular mass determination and N-terminal se- quence analysis}

The purified lectin appeared as a single band with a molecular mass of $16 \mathrm{kDa}$ in SDS/PAGE (Fig. 3) and a single peak with a molecular mass of $32 \mathrm{kDa}$ in FPLC gel filtration (Fig. 2). Thus it appears that the purified lectin is composed of two identical subunits, each with a molecular mass of $16 \mathrm{kDa}$. The $\mathrm{N}$-terminal sequence of the lectin was DILMGTYGML, different from the other mushroom lectins shown in Table 2.

Sugar specificity, thermostability, $\mathrm{pH}$ stability, and effect of cations on hemagglutinating activity

Among the variety of sugars tested, inulin at a concentration of $25 \mathrm{mM}$ was able to inhibit 16

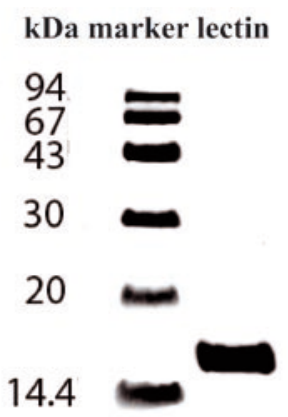

Figure 3. SDS/PAGE of purified $P$. adiposa lectin.

Fraction SU2 from gel filtration was run on SDS/ polyacrylamide gel. Molecular mass markers (left lane) are: phosphorylase b (94 kDa), bovine serum albumin (67 kDa), ovalbumin (43 kDa), carbonic anhydrase (30 $\mathrm{kDa})$, soybean trypsin inhibitor $(20 \mathrm{kDa})$ and $\alpha$-lactalbumin $(14.4 \mathrm{kDa})$, all from GE Healthcare. hemagglutinating units of the lectin. The hemagglutinating activity of the lectin was stable between 20 and $50^{\circ} \mathrm{C}$. The activity decreased by $75 \%$ at $60^{\circ} \mathrm{C}$. At and above $70^{\circ} \mathrm{C}$ the hemagglutinating activity was undetectable (Table 3). The lectin was stable in $6 \mathrm{mM}(\mathrm{pH} \mathrm{2.2)}, 12.5 \mathrm{mM}(\mathrm{pH} \mathrm{1.9)}$, and $25 \mathrm{mM}$ $(\mathrm{pH}$ 1.6) $\mathrm{HCl}$. The activity was reduced by $75 \%$ in $50 \mathrm{mM} \mathrm{HCl}(\mathrm{pH} \mathrm{1.3)}$, and disappeared altogether at $100 \mathrm{mM} \mathrm{HCl}(\mathrm{pH}$ 1.0) (Table 4). Full hemagglutinating activity was observed in $6 \mathrm{mM}(\mathrm{pH} 11.8), 12.5$ $\mathrm{mM}$ (pH 12.1), $25 \mathrm{mM}$ (pH 12.4), and $50 \mathrm{mM} \mathrm{NaOH}$ ( $\mathrm{pH}$ 12.7). Only $25 \%$ of the activity remained in 100 $\mathrm{mM} \mathrm{NaOH}(\mathrm{pH}$ 13.0). The activity vanished in 200 $\mathrm{mM} \mathrm{NaOH}$ ( $\mathrm{pH}$ 13.3) (Table 4). The hemagglutinating activity was unaffected in the presence of $\mathrm{Ca}^{2+}$, $\mathrm{Mg}^{2+}, \mathrm{Mn}^{2+}, \mathrm{Zn}^{2+}, \mathrm{Hg}^{2+}$, and $\mathrm{Fe}^{3+}(6.25-50 \mathrm{mM})$, but was increased by $\mathrm{Cu}^{2+}, \mathrm{Al}^{3+}(12.5-50 \mathrm{mM})$, and $\mathrm{Fe}^{2+}$ (25-50 mM) (Table 5).

\section{Other biological activities}

The lectin inhibited the proliferation of Hep G2 and MCF tumor cells with an $\mathrm{IC}_{50}$ value of 2.1 $\mu \mathrm{M}$ and about $3.2 \mu \mathrm{M}$, respectively (Fig. 4). HIV-1 reverse transcriptase was inhibited with an $\mathrm{IC}_{50}$ of $1.9 \mu \mathrm{M}$ (Fig. 5). The lectin lacked antifungal and ribonuclease activities (not shown).

\section{DISCUSSION}

Pholiota adiposa lectin (PAL) isolated in the present investigation differs from lectins purified from other Agaricales mushrooms. PAL was purified using three kinds of columns: DEAE-cellulose, CM-cellulose and Superdex 75. PAL is adsorbed on DEAE-cellulose and CM-cellulose columns and eluted with $150 \mathrm{mM} \mathrm{NaCl}$ and $50 \mathrm{mM} \mathrm{NaCl}$, respectively. 
Table 4. Effects of $\mathrm{NaOH}$ and $\mathrm{HCl}$ on hemagglutinating activity of $P$. adiposa lectin.

Initial hemagglutinating activity was $16 \mathrm{U}$.

\begin{tabular}{lccc}
\hline $\mathrm{pH}$ Value & Hemagglutinating activity remaining $(\%)$ & $\mathrm{pH}$ Value & Hemagglutinating activity remained $(\%)$ \\
\hline 0.7 & 0 & $9.0-11.5$ & 100 \\
1.0 & 0 & 11.8 & 100 \\
1.3 & 25 & 12.1 & 100 \\
1.6 & 100 & 12.4 & 100 \\
1.9 & 100 & 12.7 & 100 \\
2.1 & 100 & 13.0 & 25 \\
$2.1-4.5$ & 100 & 13.3 & 0 \\
\hline
\end{tabular}

Table 5. Effects of cations on hemagglutinating activity of $P$. adiposa lectin.

Initial hemagglutinating activity was $16 \mathrm{U}$.

\begin{tabular}{lllll}
\hline \multicolumn{5}{l}{ Hemagglutinating activity $(\%)$} \\
\hline Cation & $50 \mathrm{mM}$ & $25 \mathrm{mM}$ & $12.5 \mathrm{mM}$ & $6.25 \mathrm{mM}$ \\
$\mathrm{Cu}^{2+}$ & 200 & 200 & 200 & 100 \\
$\mathrm{Fe}^{2+}$ & 200 & 200 & 100 & 100 \\
$\mathrm{Al}^{3+}$ & 200 & 200 & 200 & 100 \\
\hline
\end{tabular}

It is strongly adsorbed on SP-Sepharose column and no activity can be eluted with $3 \mathrm{M} \mathrm{NaCl}$. Compared with PAL, a lectin named PAA isolated from Pholiota aurivella, which belongs to the same genus as $P$. adiposa, is adsorbed during affinity chromatography on a fetuin, asialofetuin, BSM, or asialo-BSM column, and during ion exchange chromatography on DEAE-Toyopearl and CM-Toyopearl. No lectin activity is found when a variety of eluents is used. Only $0.1 \%$ SDS can elute the lectin from the adsorbents or matrices (Kawagishi et al., 1991).

$\mathrm{PAL}$ possesses an $\mathrm{N}$-terminal sequence that bears little resemblance to some of the published Agaricales mushroom lectins, such as those from

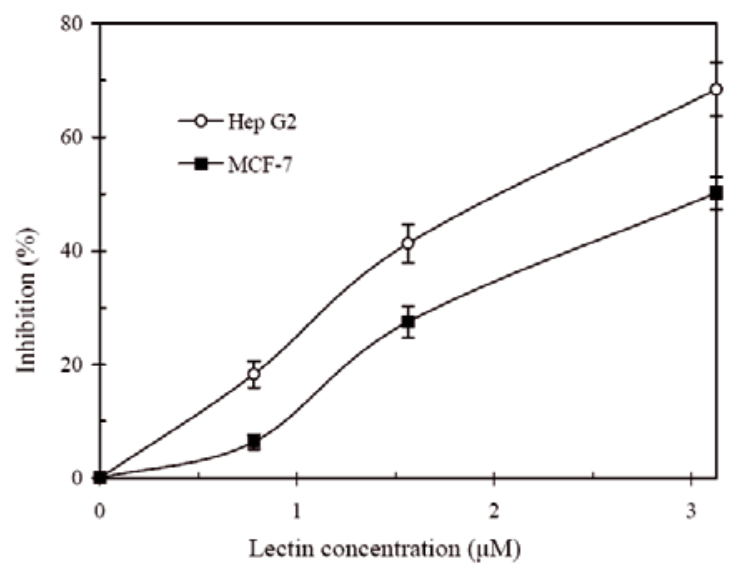

Figure 4. In vitro inhibitory effect of $P$. adiposa lectin on proliferation of Hep G2 and MCF-7 cancer cell lines.

Results represent mean \pm S.D. $(n=3)$. The $\mathrm{IC}_{50}$ toward Hep G2 cells and MCF7 cells is $2.1 \mu \mathrm{M}$ and close to $3.2 \mu \mathrm{M}$, respectively.
Agaricus bisporus, Agrocybe aegerita, Coprinopsis cinerea, Flammulina velutipes, Laccaria bicolor, Marasmius oreades, Pholiota aurivella, and Pleurotus cornucopiae (shown in Table 2) (Kawagishi et al., 1991; Crenshaw et al., 1995; Ko et al., 1995; Oguri et al., 1996; Kruger et al., 2002; Zhao et al., 2003; Nagata et al., 2005; Martin et al., 2008; Walti et al., 2008). Similarly to the Agaricus edulis II, Ischnoderma resinosum, Pleurotus citrinopileatus, and P. comucopiae PCL-a lectins (Guillot et al., 1997; Li et al., 2008), PAL is composed of two identical subunits with a molecular mass of $16 \mathrm{kDa}$.

Carbohydrate specificity is an important characteristic of lectins. It is interesting in that only inulin, a plant polysaccharide, is able to inhibit the hemagglutinating activity of PAL. To date only a few inulin-specific lectins have been reported (Liu et al., 2004; Feng et al., 2006). Hence PAL may be used in the production of immobilized lectin for affinity chromatography.

In the present study, $\mathrm{Cu}^{2+}, \mathrm{Fe}^{2+}$, and $\mathrm{Al}^{3+}$ ions increased the hemagglutinating activity of PAL when present at $12.5 \mathrm{mM}, 25 \mathrm{mM}$, and $12.5 \mathrm{mM}$, respectively, while $\mathrm{Ca}^{2+}, \mathrm{Mg}^{2+}, \mathrm{Mn}^{2+}, \mathrm{Zn}^{2+}, \mathrm{Hg}^{2+}$, and $\mathrm{Fe}^{3+}$ ions were devoid of any effect. Different mushroom lectins may be affected differently by the ions. $\mathrm{Al}^{3+}$ ions strongly increase the hemagglutinating ac-

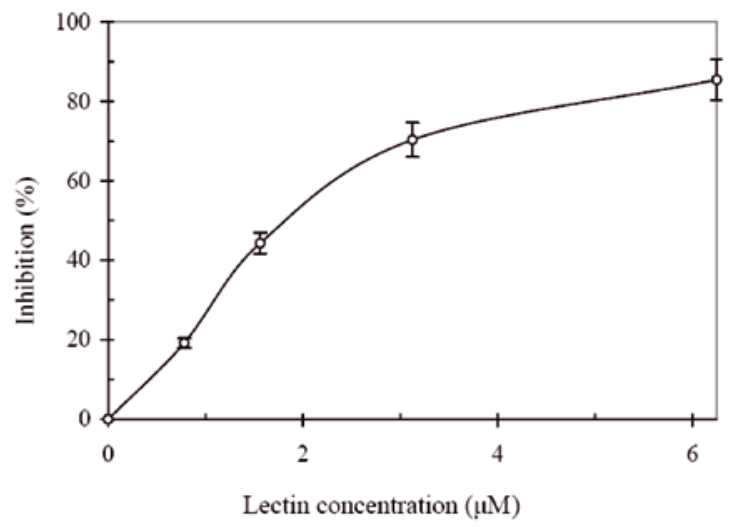

Figure 5. Inhibitory effect of $P$. adiposa lectin on activity of HIV-1 reverse transcriptase.

Results represent mean \pm S.D. $(n=3)$. The $\mathrm{IC}_{50}$ is $1.9 \mu \mathrm{M}$. 
Table 6. Comparison of characteristics of $P$. adiposa and $P$. aurivella lectins.

\begin{tabular}{|c|c|c|}
\hline Characteristics & P. adiposa lectin & P. aurivella lectin \\
\hline \multicolumn{3}{|l|}{ Chromatographic behavior } \\
\hline DEAE ion exchanger & adsorbed, eluted with $150 \mathrm{mM} \mathrm{NaCl}$ & $\begin{array}{l}\text { tenaciously adsorbed, eluted only with } 0.1 \% \\
\text { SDS }\end{array}$ \\
\hline Affi-gel blue gel & unadsorbed & not used \\
\hline $\mathrm{CM}$ ion exchanger & adsorbed, eluted with $50 \mathrm{mM} \mathrm{NaCl}$ & $\begin{array}{l}\text { tenaciously adsorbed, eluted only with } 0.1 \% \\
\text { SDS }\end{array}$ \\
\hline Molecular mass (kDa) & 32 & more than several hundred \\
\hline Subunit molecular mass (kDa) & 16 & 18 \\
\hline N-terminal sequence & DILMGTYGML & YSVTTPNSVKGGTNQPGA \\
\hline Thermostability & up to $50^{\circ} \mathrm{C}$ & not determined \\
\hline pH stability & pH 1.6-12.7 & $\mathrm{pH} 6-10.5$ \\
\hline Sugar specificity & $\begin{array}{l}\text { hemagglutinating activity inhibited by the } \\
\text { polysaccharide inulin and not by simple } \\
\text { sugars }\end{array}$ & $\begin{array}{l}\text { hemagglutinating activity inhibited by glyco- } \\
\text { proteins and not by simple sugars }\end{array}$ \\
\hline $\begin{array}{l}\text { Effect of cations on } \\
\text { hemagglutinating activity }\end{array}$ & activity enhanced by $\mathrm{Cu}^{2+}, \mathrm{Fe}^{2}$, and $\mathrm{Al}^{3+}$ & no effect \\
\hline Antifungal activity & no effect & not determined \\
\hline Antiproliferative activity & $\mathrm{IC}_{50}=2-3 \mu \mathrm{M}$ & not determined \\
\hline HIV-1 RT inhibitory activity & $\mathrm{IC}_{50}=1.9 \mu \mathrm{M}$ & not determined \\
\hline
\end{tabular}

tivity of Pleurotus ostreatus lectin (Wang et al., 2000), but do not affect the lectin from Schizophyllum commune (Han et al., 2005). $\mathrm{Ca}^{2+}, \mathrm{Mg}^{2+}, \mathrm{Mn}^{2+}$, and $\mathrm{Zn}^{2+}$ ions do not affect the hemagglutinating activity of lectins isolated from Amanita pantherina (Zhuang et al., 1996), G. frondosa (Kawagishi et al., 1990), and Hericium erinaceum (Kawagishi et al., 1994), but inhibit a Schizophyllum commune lectin (Han et al., 2005).

PAL is stable in the presence of $25 \mathrm{mM} \mathrm{HCl}$ and $50 \mathrm{mM} \mathrm{NaOH}$. It exhibits some similarity to the lectin from Armillaria luteo-virens (Feng et al., 2006). Mushroom lectins differ from one another in thermostability. The hemagglutinating activity of PAL decreases when the lectin is exposed to temperatures above $50^{\circ} \mathrm{C}$. At and above $70^{\circ} \mathrm{C}$ the lectin activity is completely abolished. The lectin from Ganoderma capense is not affected after exposure to $100^{\circ} \mathrm{C}$ for 60 min (Ngai \& Ng, 2004), while the hemagglutinating activity of lectins from $P$. ostreatus is reduced at or above $40^{\circ} \mathrm{C}$ (Wang et al., 2000).

PAL is characterized by an ability to inhibit proliferation of two tumor cell lines, Hep G2 and MCF-7. The $\mathrm{IC}_{50}$ toward Hep G2 cells and MCF7 cells is $2.1 \mu \mathrm{M}$ and near $3.2 \mu \mathrm{M}$, respectively. Lectins from $A$. bisporus, $P$. ostreatus, Tricholoma mongolicum, and Volvariella volvacea have antitumor activity in vivo or antiproliferative activity in vitro (Wang et al., 1996; 1998; 2000). The potent antiproliferative activity of PAL is remarkable and hopefully it can be developed into an agent for cancer therapy. HIV RT is a key enzyme of the HIV life cycle. Screening of HIV RT inhibitors is currently a strategy to search for anti-HIV drugs. It is worth mentioning that PAL manifests a potent inhibitory activity toward HIV-1 RT with an $\mathrm{IC}_{50}$ of $1.9 \mu \mathrm{M}$.
Compared with many other lectins, P. adiposa lectin has significant inhibitory activity toward HIV-1 reverse transcriptase. It is possible that the mechanism of inhibition is analogous to the protein-protein interaction involved in the inhibition of HIV-1 reverse transcriptase by the homologous protease (Bottcher \& Grosse, 1997).

When compared with $P$. aurivella lectin, the $P$. adiposa lectin displays many differences in chromatographic behavior, molecular mass, N-terminal sequence, and effect of cations on hemagglutinating activity. For $P$. aurivella lectin, many biological activities, including antifungal, antiproliferative, and HIV-1 RT inhibitory activities have not been determined (Table 6) (Kawagishi et al., 1991).

In summary, a lectin with a distinctive $\mathrm{N}$ terminal sequence, carbohydrate specificity, and potent antiproliferative activity was isolated from $P$. adiposa fruiting bodies. It represents an addition to the existing list of mushroom lectins since it is the second Strophariaceae lectin and the second lectin isolated from a mushroom belonging to the Pholiota genus.

\section{Acknowledgements}

This work was financially supported by National Grants of China (nyhyzx07-008, 2007BAD89B00 and 2010CB732202).

\section{REFERENCES}

Bottcher M, Grosse F (1997) HIV-1 protease inhibits its homologous reverse transcriptase by protein-protein interaction. Nucleic Acids Res 25: 1709-1714. 
Cho SM, Lee YM, Lee DH, Chun HK, Lee JS (2006) Effect of a Pholiota adiposa extract on fat mass in hyperlipidemic mice. Mycobiol 34: 236-239.

Crenshaw RW, Harper SN, Moyer M, Privalle LS (1995) Isolation and characterization of a cDNA clone encoding a lectin gene from Agaricus bisporus. Plant Physiol 107: 1465-1466.

Feng K, Liu QH, Ng TB, Liu HZ, Li JQ, Chen G, Sheng HY, Xie ZL, Wang HX (2006) Isolation and characterization of a novel lectin from the mushroom Armillaria luteo-virens. Biochem Biophys Res Commun 345: 1573-1578.

Guillot J, Konska G (1997) Lectins in higher fungi. Biochem Syst Ecol 25: 203-230.

Han CH, Liu QH, Ng TB, Wang HX (2005) A novel homodimeric lactose-binding lectin from the edible split gill medicinal mushroom Schizophyllum commune. Biochem Biophys Res Commun 336: 252-257.

Ho JCK, Sze SCW, Shen WZ, Liu WK (2004) Mitogenic activity of edible mushroom lectins. Biochim Biophys Acta 1671: 9-17.

Izawa H, Aoyagi Y (2006) Inhibition of angiotensin converting enzyme by mushroom. J Jap Soc Food Sci Technol 53: 459-465.

Kawagishi H, Nomura A, Mizuno T, Kimura A, Chiba S (1990) Isolation and characterization of a lectin from Grifola frondosa fruiting bodies. Biochim Biophys Acta 1034: 247-252.

Kawagishi H, Abe Y, Nagata T, Kimura A, Chiba S (1991) A lectin from the mushroom Pholiota aurivella. Agric Biol Chem 55: 2485-2489.

Kawagishi H, Mori H, Uno A, Kimura A, Chiba S (1994) A sialic acid-binding lectin from the mushroom Hericium erinaceum. FEBS Lett 340: 56-58.

Ko JL, Hsu CI, Lin RH, Kao CL, Lin JY (1995) A new fungal immunomodulatory protein, FIP-fve isolated from the edible mushroom, Flammulina velutipes and its complete amino acid sequence. Eur J Biochem 228: 244-249.

Koo KC, Lee DH, Kim JH, Yu HE, Park JS, Lee JS (2006) Production and characterization of antihypertensive angiotensin I-converting enzyme inhibitor from Pholiota adiposa. J Microbiol Biotechnol 16: 757-763.

Kruger RP, Winter HC, Simonson-Leff N, Stuckey JA, Goldstein IJ, Dixon JE (2002) Cloning, expression, and characterization of the Galalpha 1,3Gal high affinity lectin from the mushroom Marasmius oreades. J Biol Chem 277: 15002-15005.

Laemmli UK, Favre M (1973) Maturation of the head of bacteriophage T4. I. DNA packaging events. J Mol Biol 80: 575-599.

Li YR, Liu QH, Wang HX, Ng TB (2008) A novel lectin with potent antitumor, mitogenic and HIV-1 reverse transcriptase inhibitory activities from the edible mushroom Pleurotus citrinopileatus. Biochim Biophys Acta 1780: 51-57.

Liu QH, Wang HX, Ng TB (2004) Isolation and characterization of a novel lectin from the wild mushroom Xerocomus spadiceus. Peptides 25: 7-10.

Liu QH, Wang HX, Ng TB (2006) First report of a xylosespecific lectin with potent hemagglutinating, antiproliferative and anti-mitogenic activities from a wild ascomycete mushroom. Biochim Biophys Acta 1760: 1914-1919.
Martin F, Aerts A, Ahren D, Brun A, Danchin EG, Duchaussoy F, Gibon J, Kohler A (2008) The genome of Laccaria bicolor provides insights into mycorrhizal symbiosis. Nature 452: 42-43.

Nagata Y, Yamashita M, Honda H, Akabane J, Uehara K, Saito A, Sumisa F, Nishibori K, Oodaira Y (2005) Characterization, occurrence, and molecular cloning of a lectin from Grifola frondosa: jacalin-related lectin of fungal origin. Biosci Biotechnol Biochem 69: 2374-2380.

$\mathrm{Ng}$ TB (2004) Peptides and proteins from fungi. Peptides 25: 1055-1073.

Ngai PHK, Ng TB (2004) Isolation of a mushroom (Ganoderma carpense) lectin with spectacular thermostability, potent mitogenic activity on splenocytes and antiproliferative activity on tumor cells. Biochem Biophys Res Commun 314: 988-993.

Oguri S, Ando A, Nagata Y (1996) A novel developmental stage-specific lectin of the basidiomycete Pleurotus cornucopiae. J Bacteriol 178: 5692-5698.

Pemberton RT (1984) Agglutinins (lectins) from some British higher fungi. Mycolog Res 98: 277-290.

Walti MA, Walser PJ, Thore S, Grünler A, Bednar M, Künzler M, Aebi M (2008) Structural basis for chitotetraose coordination by CGL3, a novel galectin-related protein from Coprinopsis cinerea. J Mol Biol 379: 146-159.

Wang HX, Ng TB (2004) Purification of a novel low-molecular-mass laccase with HIV-1 reverse transcriptase inhibitory activity from the mushroom Tricholoma giganteum. Biochem Biophys Res Commun 315: 450-454.

Wang HX, Ng TB (2006) A ribonuclease from the wild mushroom Boletus griseus. Appl Microbiol Biotechnol 72: 912-916.

Wang HX, Liu WK, Ng TB, Ooi VEC, Chang ST (1996) The immunomodulatory and antitumor activities of lectins from the mushroom Tricholoma mongolicum. Immunopharmacol 31: 205-211.

Wang HX, Ng TB, Ooi VEC (1998) Lectins from mushrooms. Mycol Res 102: 897-906.

Wang HX, Gao JQ, Ng TB (2000) A new lectin with highly potent antihepatoma and antisarcoma activities from the oyster mushroom Pleurotus ostreatus. Biochem Biophys Res Commun 275: 810-816.

Wang HX, Ng TB, Liu Q (2002) Isolation of a new heterodimeric lectin with mitogenic activity from fruiting bodies of the mushroom Agrocybe cylindracea. Life Sci 70: 877-886.

Yu HE, Lee DH, Seo GS, Cho SM, Lee JS (2007) Characterization of a novel $\beta$-hydroxy- $\beta$-methyl glutaryl coenzyme a reductase-inhibitor from the mushroom, Pholiota adiposa. Biotechnol Bioproc Eng 12: 618-624.

Zhao C, Sun H, Tong X, Qi Y (2003) An antitumour lectin from the edible mushroom Agrocybe aegerita. Biochem J 374: 321-327.

Zhao Y, Li K, Zhang Y (2007) Anti-tumor function of polysaccharides from Pholiota adiposa mycelium. Acta Edulis Fungi 14: 49-54.

Zhuang C, Murata T, Usui T, Kawagishi H, Kobayashi K (1996) Purification and characterization of a lectin from the toxic mushroom Amanita pantherina. Biochim Biophys Acta 1291: 40-44. 